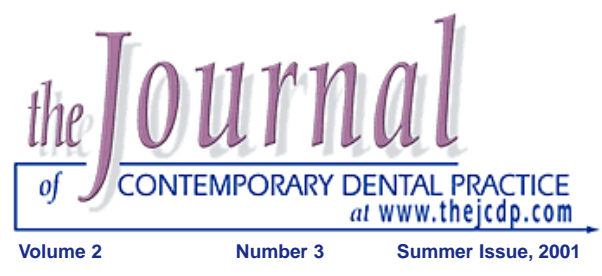

\title{
Back \& Neck Problems Among Dentists and Dental Auxiliaries
}

\author{
Khalid A. Al Wazzan, BDS, MS; \\ Khalid AImas, BDS, MSc, FRACDS, FDSRC, DDPHFi \\ Salah E. Al Shethri, BDS; Mohammed Q. Al Qahtani, BDS
}

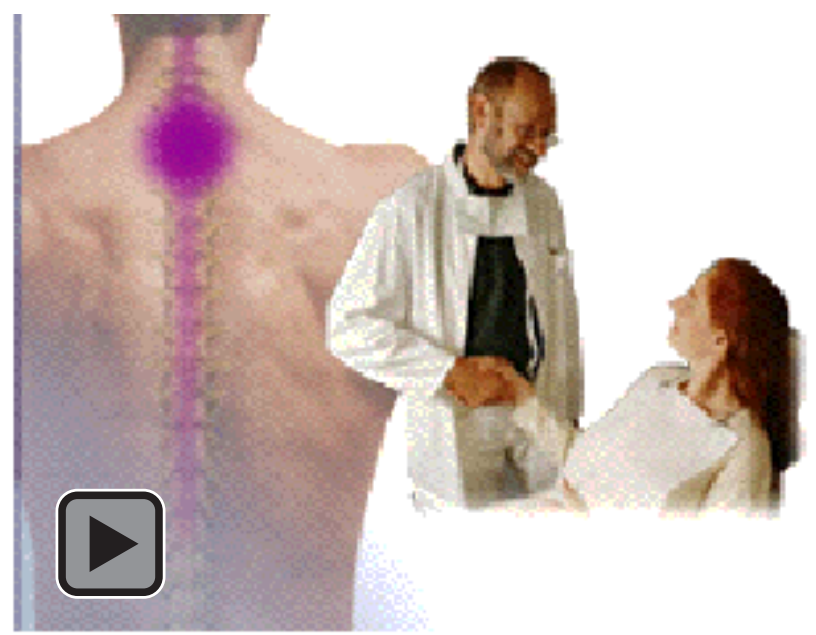

\begin{abstract}
In the practice of dentistry, stress, tension, and postural practices can contribute to back and neck problems. Two hundred and four dentists and dental auxiliary (87 males and 117 females) in Riyadh city, Saudi Arabia were surveyed to determine the prevalence of postural problems. The candidates were interviewed and observed during practice. The data obtained showed that $111(54.4 \%)$ of the subjects complained of neck pain and 150 (73.5\%) complained of back pain. Only $37 \%$ of those complaining of back pain sought medical help. Within the limitations of this study, it might be concluded that neck and back pain among dental personnel are not of a severe nature.

Keywords: Backache, dental personnel, dental team, ergonomics, neck pain, occupational hazard, posture

Citation: Al Wassan KA, Almas K, Al Shethri SE, et. al. Back \& Neck Problems Among Dentists and Dental Auxiliaries. J Contemp Dent Pract 2001;(2)3: 017-030
\end{abstract}

(c) Seer Publishing 


\section{Introduction}

The dental team is at high risk of neck and back problems due to the limited work area and impaired vision associated with the oral cavity. These working restrictions frequently cause a clinician to assume stressful body positions to achieve good access and visibility inside the oral cavity. Furthermore, dental procedures are usually long and require much more concentration during work.

Back pain is one of the most common and troublesome of complaints; its exact causes are legion and an exact diagnosis is often difficult. ${ }^{1}$ Back problems have been cited as the second most common reason for missing work in an industrial population in the United States. ${ }^{2}$
It has been stated that the most common sites of pain among dentists and dental auxiliaries are in the areas of the cervical and lumbar vertebrae.,.$^{3,45}$ The shape of the vertebral column, aging changes, weak muscles, postural practice, movements, lifting techniques, and mechanical stress have been identified as factors that contribute to neck and back pain in general. ${ }^{6}$ One investigator focused on neck and back pain among dentists and dental auxiliaries. The study highlighted that stress, postural practices (bending and twisting trying to gain better access and visibility within the oral cavity), as well as prolonged working times leads to fatigue. ${ }^{7}$ Various investigators have pointed out the common postural faults among dentists and dental auxiliaries are craning and/or excessive bending and twisting of the neck, bending forward from the waist, elevation of the shoulders, and general bending or twisting of the back and neck. ${ }^{8,9,10,11,12}$ (Figures. 1, 2, and 3)

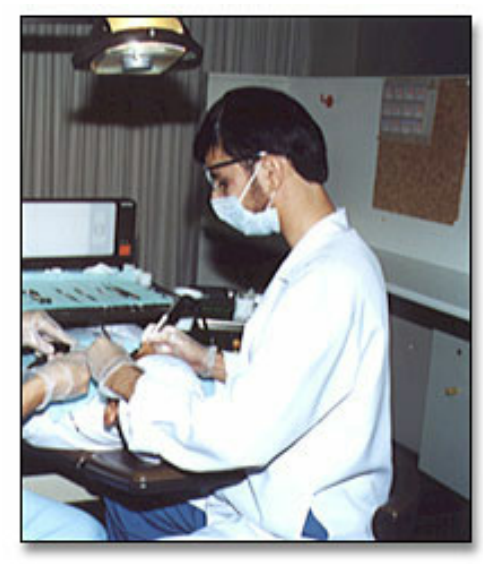

Figure 1. Typical working posture: Shoulders and thighs parallel to the ground and feet flat on the floor. The back should not be held rigidly straight but should be maintained in a gradual curve, supported by the back-support of the chair. Elbows held close to the body and the neck relatively erect, with the head tipped slightly forward.
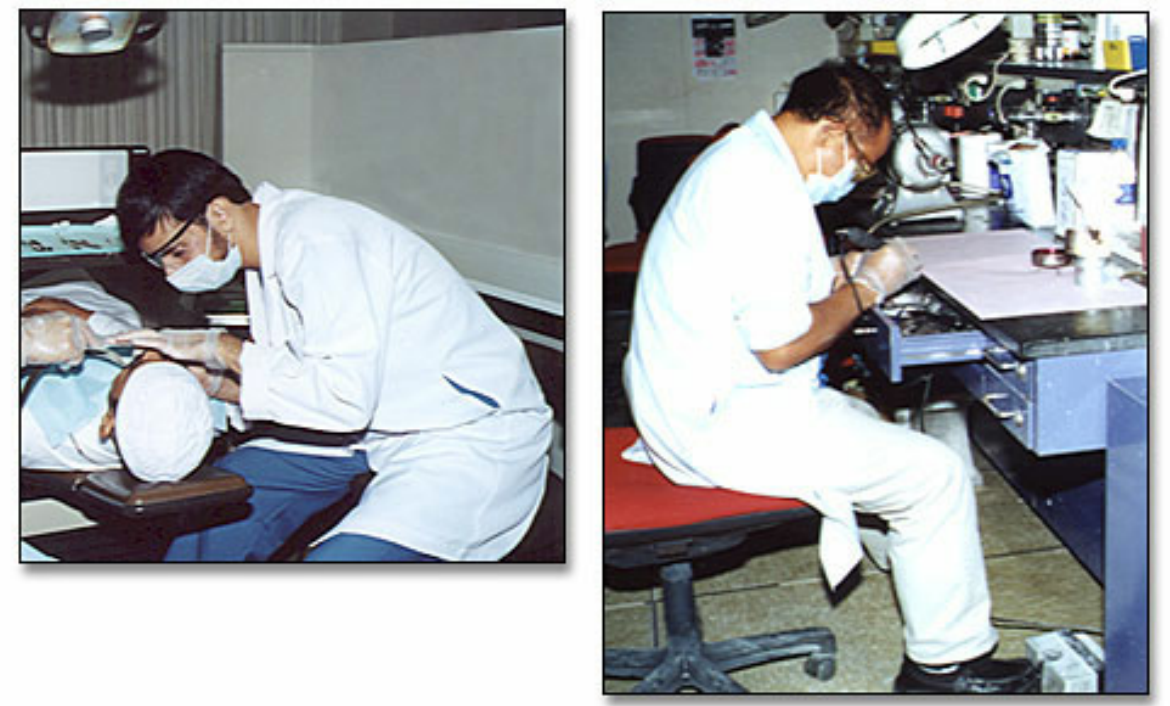

Figures $2 \mathrm{a}$ and $2 \mathrm{~b}$. Excessive forward bending: The soft tissues surrounding the spinal column (i.e., muscles, ligaments, and joint capsules) are stretched and strained. Stresses are also put on the spinal column and spinal core. 


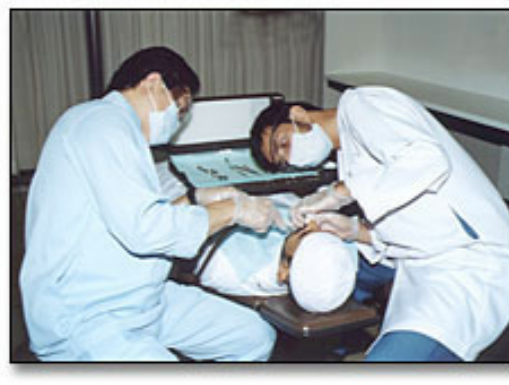

Since the 1980's, studies have reported a high prevalence of back pain among dentists. A survey of 432 dentists in Denmark, of which $90.4 \%$ were utilizing the sit-down operating technique, showed that $60 \%$ suffered from pain in the neck and back. $^{6}$ Another survey of 465 Toronto area, Canadian dentists found that $62.2 \%$ had suffered back and neck pain at sometime in their lives, while $36.3 \%$ were currently suffering from such problems. ${ }^{6}$ Seventy percent of dentists in this survey had never missed work because of their back problem and $62 \%$ of those who had backaches had missed less than one week. This might lead to the conclusion that back problems among dentists are not of a severe nature. In a study in New South Wales, Australia, $59 \%$ of the dentists that participated in the study reported trunk pain during the previous month. ${ }^{5}$ A survey of dentists in Southern Thailand reported that $63.3 \%$ had experienced back pain. ${ }^{13}$

Dental auxiliaries also experience back problems associated with their work. A survey of American hygienists in the state of Minnesota revealed that $68 \%$ reported musculoskeletal pain. ${ }^{4}$ Still another study demonstrated that both dentists and dental assistants experienced back and neck discomfort, and the discomfort significantly increased as the working day progressed. ${ }^{14}$ They reported that dentists experienced a greater level of discomfort than dental assistants.

Little has changed since 1949 when Biller first reported the prevalence of back pain among dentists (65\%). ${ }^{15}$ In 1989, Bassett concluded that despite the use of improved dental equipment, operating in a seated position using the four handed dentistry technique, and increasing frequency of exercise, the incidence of back problems has not decreased over the last 15 years. ${ }^{6}$
He went on to state that for many dentists, backaches are likely to be related to muscular tension and poor working postures. As a preventive measure, Bassett recommended dental students should be taught relaxation techniques early in their clinical training, and they should be taught correct working positions at chairside.

The aims of this study were to determine the prevalence of neck and back problems among dentists and dental auxiliaries in Riyadh, Saudi Arabia and to develop some guidelines to reduce the dental occupational hazards.

\section{Materials and Methods}

The survey was conducted on a sample of 250 dentists and dental auxiliaries in Riyadh, Saudi Arabia. The response rate was $82 \%(n=204)$.

The self-administered questionnaire was composed of 15 questions about background data (i.e., gender, sex, weight, etc.), 11 questions about specific information on neck and back pain and routine practice postures while working at chairside, and the frequency worked at chairside. Multiple choice questions were used. The questionnaire was pilot-tested on a group of 10 dental personnel prior to finalization.

After completion of the questionnaire, the candidates were interviewed to clarify any confusion and to furnish any missing data. The candidates were observed in their dental practices to analyze their postural positions during work. The two observers were calibrated by training sessions with an orthopedic surgeon with regard to performing the interview and the observation of the candidate's postural positions.

The candidates were selected from the following five different dental care facilities in Riyadh city:

- King Saud University College of Dentistry

- Riyadh Armed Forces Hospital

- Riyadh Medical Complex

- Primary Health Care Centers

- Some private dental clinics in Riyadh

The Journal of Contemporary Dental Practice, Volume 2, No. 3, Summer Issue, 2001 
Table 1. The subjects classification by profession and gender

\begin{tabular}{|l|l|l|l|}
\hline Profession & Male & Female & Total \\
\hline Dentist & 53 & 38 & $91(44.60)$ \\
\hline Dental Assistant & 5 & 67 & $72(35.30)$ \\
\hline Dental Technician & 24 & 5 & $29(14.20)$ \\
\hline Dental Hygienist & 5 & 7 & $12(5.90)$ \\
\hline Total & $87(42.60)$ & $117(57.40)$ & $204(100)$ \\
\hline Percentages are in parenthesis () & ) & & \\
\hline
\end{tabular}

Table 2. Frequency of age range of the subjects

\begin{tabular}{|c|c|c|}
\hline Age group years & Number & Percentage \\
\hline $21-30$ & 86 & $(42.20)$ \\
\hline $31-40$ & 95 & $(46.60)$ \\
\hline Over 40 & 23 & $(11.27)$ \\
\hline Total & 204 & $(100)$ \\
\hline
\end{tabular}

The selection of these centers was dependent on their willingness to participate in the study.

The data was analyzed using common database and statistical software.

\section{Results}

Among the 204 respondents, 91 were dentists, 72 dental assistants (DA), 29 dental technicians (DT), and 12 dental hygienists (DH). The sample population included 87 males, 117 females, with ages ranging from 21-56 years. (Tables 1 and 2)

Table 3 lists the relation between the prevalence of neck and back pain relative to the nature of the job. It was found that dentists had relatively more neck and back pain as compared to auxiliary staff. Neck pain was significantly higher among dentists $(p=0.0122)$. Table 4 shows that there was no relationship of neck and back pain to body weight $(p=0.8813$ and $p=0.4215$ respectively).

Regarding the influence of age grouping, there was no significant difference among dentists and other personnel in neck and backache. (Table 5) Regarding the influence of weekly working hours on neck and back pain, again, there was no significant difference between different age groups. (Table 6) The number and percentages of those who missed work due to neck and backache was insignificant $(p=0.5655)$. (Table 7) Interestingly, there were significantly more who sought medical assistance due to back pain as compared to those who needed medical help for neck pain $(p=0.0384)$. (Table 8$)$

\section{Discussion}

The results of this survey showed $73.53 \%$ of the respondents had back pain some time in their lives, while neck pain was $54.41 \%$ less common. This might be due to postural practices. Observation of the candidates during work revealed that $90.69 \%$ of them had postural faults with regard to back status and $83.83 \%$ with regard to neck posture. It was found that $79.12 \%$ of the dentists had suffered back problems, which is slightly higher than the findings of similar surveys. ${ }^{5,6,13}$

The results of the present survey showed dentists had significantly more neck and back pain than dental hygienists, dental assistants, and dental technicians. The results of Visser and Straker ${ }^{14}$ also showed the dentist experienced significantly greater levels of lower back discomfort than dental assistants. These differences could be attributed 
Table 3. The relation between the prevalence of neck and back pain with nature of job

\begin{tabular}{|c|c|c|c|c|c|c|c|c|c|c|}
\hline \multirow[t]{3}{*}{ Prevalence } & \multicolumn{5}{|c|}{$\begin{array}{l}\text { Neck Pain Among } \\
\text { Professionals }\end{array}$} & \multicolumn{5}{|c|}{$\begin{array}{l}\text { Back Pain Among } \\
\text { Professionals }\end{array}$} \\
\hline & $\begin{array}{l}N \\
(\%)\end{array}$ & $\begin{array}{l}N \\
(\%)\end{array}$ & $\begin{array}{l}N \\
(\%)\end{array}$ & $\begin{array}{l}N \\
(\%)\end{array}$ & $\begin{array}{l}N \\
(\%)\end{array}$ & $\begin{array}{l}N \\
(\%)\end{array}$ & $\begin{array}{l}N \\
(\%)\end{array}$ & $\begin{array}{l}N \\
(\%)\end{array}$ & $\begin{array}{l}N \\
(\%)\end{array}$ & $\begin{array}{l}N \\
(\%)\end{array}$ \\
\hline & Dentist & $\mathrm{DA}$ & DT & $\mathrm{DH}$ & Total & Dentist & $\mathrm{DA}$ & DT & $\mathrm{DH}$ & Total \\
\hline None & $\begin{array}{c}33 \\
(36.26)\end{array}$ & $\begin{array}{c}45 \\
(62.50)\end{array}$ & $\begin{array}{c}11 \\
(37.93)\end{array}$ & $\begin{array}{c}4 \\
(33.33)\end{array}$ & $\begin{array}{c}93 \\
(45.59)\end{array}$ & $\begin{array}{c}19 \\
(29.88)\end{array}$ & $\begin{array}{c}26 \\
(36.11)\end{array}$ & $\begin{array}{c}8 \\
(27.59)\end{array}$ & $\begin{array}{c}1 \\
(8.33)\end{array}$ & $\begin{array}{c}54 \\
(26.47)\end{array}$ \\
\hline Rarely & $\begin{array}{c}40 \\
(43.96)\end{array}$ & $\begin{array}{c}22 \\
(30.56)\end{array}$ & $\begin{array}{c}10 \\
(34.48)\end{array}$ & $\begin{array}{c}6 \\
(50.00)\end{array}$ & $\begin{array}{c}78 \\
(38.24)\end{array}$ & $\begin{array}{c}39 \\
(42.86)\end{array}$ & $\begin{array}{c}32 \\
(44.44)\end{array}$ & $\begin{array}{c}15 \\
(51.72)\end{array}$ & $\begin{array}{c}6 \\
(50.00)\end{array}$ & $\begin{array}{c}92 \\
(45.10)\end{array}$ \\
\hline Regularly & $\begin{array}{c}18 \\
(19.8)\end{array}$ & $\begin{array}{c}5 \\
(6.95)\end{array}$ & $\begin{array}{c}8 \\
(27.6)\end{array}$ & $\begin{array}{c}2 \\
(16.7)\end{array}$ & $\begin{array}{c}33 \\
(16.2)\end{array}$ & $\begin{array}{c}33 \\
(36.3)\end{array}$ & $\begin{array}{c}14 \\
(19.4)\end{array}$ & $\begin{array}{c}6 \\
(20.7)\end{array}$ & $\begin{array}{c}5 \\
(41.7)\end{array}$ & $\begin{array}{c}58 \\
(28.4)\end{array}$ \\
\hline Total & $\begin{array}{c}91 \\
(100)\end{array}$ & $\begin{array}{r}72 \\
(100)\end{array}$ & $\begin{array}{c}29 \\
(100)\end{array}$ & $\begin{array}{c}12 \\
(100)\end{array}$ & $\begin{array}{r}204 \\
(100)\end{array}$ & $\begin{array}{c}91 \\
(100)\end{array}$ & $\begin{array}{r}72 \\
(100)\end{array}$ & $\begin{array}{r}29 \\
(100)\end{array}$ & $\begin{array}{c}12 \\
(100)\end{array}$ & $\begin{array}{r}204 \\
(100)\end{array}$ \\
\hline
\end{tabular}

Table 4 . The relation between the prevalence of neck and back pain with weight

\begin{tabular}{|c|c|c|c|c|c|c|c|c|c|c|}
\hline \multirow[t]{4}{*}{ Prevalence } & \multicolumn{5}{|c|}{$\begin{array}{c}\text { Neck Pain } \\
\text { Weight (Kgs.) }\end{array}$} & \multicolumn{5}{|c|}{$\begin{array}{c}\text { Back Pain } \\
\text { Weight (Kgs.) }\end{array}$} \\
\hline & $<55$ & $56-70$ & $71-85$ & $>85$ & Total & $<55$ & $56-70$ & $71-85$ & $>86$ & Total \\
\hline & $N$ & $N$ & $N$ & $N$ & $N$ & $N$ & $N$ & $N$ & $N$ & $N$ \\
\hline & $(\%)$ & $(\%)$ & $(\%)$ & $(\%)$ & $(\%)$ & $(\%)$ & $(\%)$ & $(\%)$ & $(\%)$ & $(\%)$ \\
\hline \multirow[t]{2}{*}{ None } & 26 & 37 & 18 & 12 & 93 & 13 & 25 & 10 & 6 & 54 \\
\hline & $(54.17)$ & $(43.53)$ & $(42.86)$ & $(41.38)$ & $(45.59)$ & (27.08) & (29.41) & (23.81) & (20.69) & (26.47) \\
\hline \multirow[t]{2}{*}{ Rarely } & 15 & 35 & 17 & 11 & 78 & 25 & 38 & 19 & 10 & 92 \\
\hline & (31.25) & (41.18) & $(40.48)$ & (37.93) & $(38.24)$ & (52.08) & $(44.71)$ & $(45.24)$ & (34.48) & (45.10) \\
\hline \multirow[t]{2}{*}{ Regularly } & 7 & 13 & 7 & 6 & 33 & 10 & 22 & 13 & 13 & 58 \\
\hline & $(14.6)$ & (15.3) & $(16.7)$ & $(20.7)$ & (16.2) & (20.8) & (25.88) & (30.14) & $(44.8)$ & (28.43) \\
\hline \multirow[t]{3}{*}{ Total } & 48 & 85 & 42 & 29 & 204 & 48 & 85 & 42 & 29 & 204 \\
\hline & (100) & (100) & $(100)$ & (100) & (100) & $(100)$ & (100) & (100) & $(100)$ & (100) \\
\hline & \multicolumn{5}{|c|}{$x^{2}=2.3836 \quad d f=6 \quad P=0.8813$} & \multicolumn{5}{|c|}{$x^{2}=6.015 \quad d f=6 \quad P=0.4215$} \\
\hline
\end{tabular}


Table 5. The relation between the prevalence of neck and back pain with age group

\begin{tabular}{|c|c|c|c|c|c|c|c|c|}
\hline \multirow[t]{4}{*}{ Prevalence } & \multicolumn{4}{|c|}{$\begin{array}{l}\text { Neck Pain } \\
\text { Age Groups }\end{array}$} & \multicolumn{4}{|c|}{$\begin{array}{l}\text { Back Pain } \\
\text { Age Groups }\end{array}$} \\
\hline & $N$ & $N$ & $N$ & $N$ & $N$ & $N$ & $N$ & $N$ \\
\hline & $(\%)$ & $(\%)$ & $(\%)$ & $(\%)$ & $(\%)$ & $(\%)$ & $(\%)$ & $(\%)$ \\
\hline & $21-30$ & $31-40$ & Over 40 & Total & $21-30$ & $31-40$ & Over 40 & Total \\
\hline \multirow[t]{2}{*}{ None } & 41 & 44 & 8 & 93 & 18 & 31 & 5 & 54 \\
\hline & $(47.67)$ & $(46.32)$ & $(34.78)$ & $(45.59)$ & (20.93) & (32.63) & (21.74) & (26.47) \\
\hline \multirow[t]{2}{*}{ Rarely } & 33 & 33 & 12 & 78 & 44 & 39 & 9 & 92 \\
\hline & (38.37) & (34.74) & $(52.17)$ & (38.24) & $(51.16)$ & $(41.05)$ & (39.13) & (45.10) \\
\hline \multirow[t]{2}{*}{ Regularly } & 12 & 18 & 3 & 33 & 24 & 25 & 9 & 58 \\
\hline & $(13.96)$ & (18.95) & $(13.05)$ & $(16.17)$ & (27.9) & (28.32) & (39.13) & (28.43) \\
\hline \multirow[t]{2}{*}{ Total } & 86 & 95 & 23 & 204 & 86 & 95 & 23 & 204 \\
\hline & (100) & (100) & (100) & (100) & $(100)$ & (100) & (100) & $(100)$ \\
\hline
\end{tabular}

Table 6 . The relation between the prevalence of neck and back pain with weekly working hours

\begin{tabular}{|l|c|c|c|c|c|c|}
\hline Incidence & \multicolumn{3}{|c|}{$\begin{array}{c}\text { Neck Pain } \\
\text { Weekly Working Hours }\end{array}$} & \multicolumn{3}{c|}{$\begin{array}{c}\text { Back Pain } \\
\text { Weekly Working Hours }\end{array}$} \\
\cline { 2 - 8 } & $\begin{array}{c}\text { Less than or } \\
\text { equal to 40 }\end{array}$ & More than & Total & $\begin{array}{c}\text { Less than or } \\
\text { equal to 40 }\end{array}$ & More than & Total \\
\hline None & 10 & 83 & 93 & 8 & 46 & 54 \\
\hline & $(41.66)$ & $(46.11)$ & $(45.59)$ & $(33.33)$ & $(25.56)$ & $(26.47)$ \\
\hline Rarely & 11 & 67 & 78 & 9 & 83 & 92 \\
\hline Regularly & $(45.83)$ & $(37.22)$ & $(38.24)$ & $(37.50)$ & $(46.11)$ & $(45.10)$ \\
\hline Total & 3 & 30 & 33 & 7 & 51 & 58 \\
\hline & $(12.5)$ & $(16.67)$ & $(16.17)$ & $(29.17)$ & $(28.33)$ & $(28.43)$ \\
\hline
\end{tabular}


Table 7. The number and percentage of respondents who missed work due to neck and back problems

\begin{tabular}{|l|c|c|c|c|}
\hline \multirow{2}{*}{$\begin{array}{l}\text { Missed } \\
\text { Work }\end{array}$} & \multicolumn{2}{|c|}{ Neck Pain } & \multicolumn{2}{c|}{ Back Pain } \\
\cline { 2 - 5 } & Number & Percentage & Number & Percentage \\
\hline Rarely & 24 & $(21.62)$ & 37 & $(24.66)$ \\
\hline Never & 87 & $(78.38)$ & 113 & $(75.34)$ \\
\hline Total & 111 & $(100)$ & 150 & $(100)$ \\
\hline$x^{2}=0.3303 \mathrm{df}=1 \quad \mathrm{p}=0.5655$ & & & \\
\hline
\end{tabular}

Table 8. The number and percentage of respondents complaining of neck and back problems who sought medical help

\begin{tabular}{|l|l|l|l|l|}
\hline \multicolumn{5}{|l|}{ Sought Medical Help of Those Complaining of :- } \\
\cline { 2 - 5 } & Number & Neck Pain (\%) & Number & Back Pain (\%) \\
\hline Yes & 28 & 25.23 & 56 & 37.33 \\
\hline No & 83 & 74.77 & 94 & 62.67 \\
\hline Total & 111 & 100 & 150 & 100 \\
\hline$x^{2}=4.2850 \mathrm{df}=1 \quad p=0.0384$ & & & \\
\hline
\end{tabular}

to the mental stresses and postural positions inherent in the dentists' work, resulting in more strain on their spine while working. The comparative results of the present study were contrary to findings about the work of dental assistants. The nature of a dental assistant's work was found to be less stressful, with less strain on the spine. The dental assistant's work assignments allow for greater mobility than either the dentist or hygienist. The operator function is more constrained, while the greater mobility of the dental assistant allows frequent postural changes throughout the working day. This mobility helps to avoid the prolonged static loading of the spine.

Among the dental team members, neck pain increased with age. Younger dentists and dental auxiliaries suffered more from back pain more than their older counterparts, but these differaences were not statistically significant. Other studies have also identified there is no relationship between age and back pain., ${ }^{5,13}$ It may be reasonable to assume that both younger and older dental personnel have similar types of postural problems.

It was found that weight had a minor effect on neck and back pain. The results also showed the increase in weekly working hours increased the prevalence of back pain and had little effect on the incidence of neck pain. This could be attributed to the practicing of back postural faults more than neck postural faults. However no significant difference was observed overall which is in concordance with another study. ${ }^{13}$

Finally of those who had neck pain $(54.41 \%)$ and back pain $(73.53 \%)$ only $21.62 \%$ missed work due to neck pain and only $24.66 \%$ due to back pain. This is less than the $62 \%$ reported by Bassett. $^{6}$ It is important to note that selfemployed dentists may suffer direct loss of income if they are unable to work due to their physical limitations and, therefore, under report pain and absence from work due to pain. On the other hand, only $25.32 \%$ and $37.33 \%$ sought medical help for neck and back pain respectively. Also this is less than the $70 \%$ reported by Bassett. ${ }^{6}$ This indicates postural problems cause a minimal disruption of the working hours of dental professionals in Riyadh.

\section{Recommendations}

Within the limitations of this study, it might be concluded that neck and back pain among dental personnel are not of a severe nature in Riyadh. 
However, in order to minimize or even prevent such ailments, preventive aerobic and relaxation exercises should be included in the weekly activities of dental personnel. Such a practice would (1) help dental professionals avoid future physical limitations or handicaps and (2) help them remain productive for longer periods of time during their professional lives. This will also help in improving the quality of care they can render to their patients if they are pain free during clinical procedures.

\section{Aerobic Exercises}

Aerobic exercise has been reported to improve or prevent back pain. ${ }^{16}$ In general, exercise programs that facilitate weight loss, trunk strengthening, and the stretching of musculotendinous structures appear to be helpful in alleviating low back pain. A 30-minute aerobic program three times a week is ideal for overall fitness.

Exercises to promote strengthening of the muscles that support the spine (i.e., the oblique abdominal and spinal extensor muscles) should be considered. (Figure 4 and Figure 5) An effective program may include a warm-up period, about 30 minutes of aerobic activity, isolated muscle group work (trunk muscles), and a cool-down period. Walking and/or water exercise are also recommended.

Dental professionals may need to take a break from exercise if it aggravates back pain. It is recommended that dental professionals confirm with their doctor regarding which exercises should be used to relieve back pain, to stay fit, and prevent injuring oneself again. The presence of any leg pain or other evidence of nerve injury should serve as an indication to consult a physician before beginning exercises.

\section{Relaxation Exercises}

Stress may produce a state of chronic muscle contraction that may decrease circulation and increase the concentration of the toxic products (lactic acid and potassium ions) of muscle activity. These toxic products may in turn stimulate nerve endings to generate low back pain. Deep breathing and progressive muscle relaxation exercises may serve to diminish this stress reaction. Below are some brief relaxation exercises that dentists and their auxiliary personnel may wish to employ anytime during the day, break time, or in between patients.
Exercise I: Performing a breathing exercise is one of the simplest ways to relax in any situation. Take 5-10 minutes to sit quietly and breathe deeply. Here is an example. Close your eyes and take a long, deep breath. Let it out very slowly. Now, take a second long, deep breath, As you let it out, feel yourself releasing the tensions in your mind and in your body. Just let yourself relax more and more, as you continue.

Exercise II: Clench your hands. While keeping them clenched, pull your forearms tightly up against your upper arms and raise your shoulders against your neck. While keeping those muscles tense, tense all the neck, back, and leg muscles. While keeping all these tensed, shut your eyes fairly tight and take a deep breath and hold it for 5 seconds. Then, let everything go all at once. Feel yourself letting go of all your tensions.

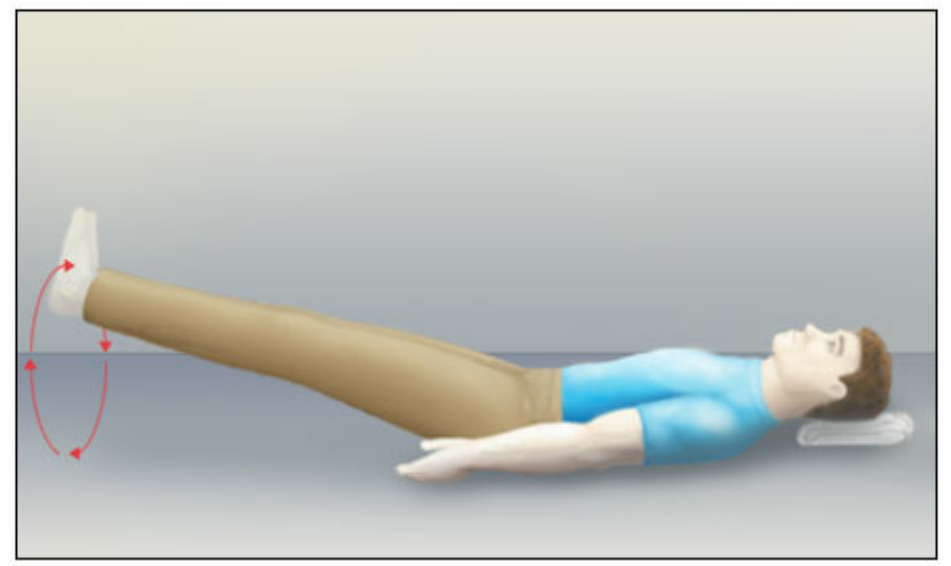

Figure 4. Trunk muscles exercise. Lie on your back, raise your legs up to 45 degrees from the floor, without bending you knees, make a circular movement of 30 $\mathrm{cm}$. diameter, five times clockwise and five times counter clockwise. Take a rest for a few seconds, then repeat the exercise. If you cannot do both legs together, you can do it one by one.

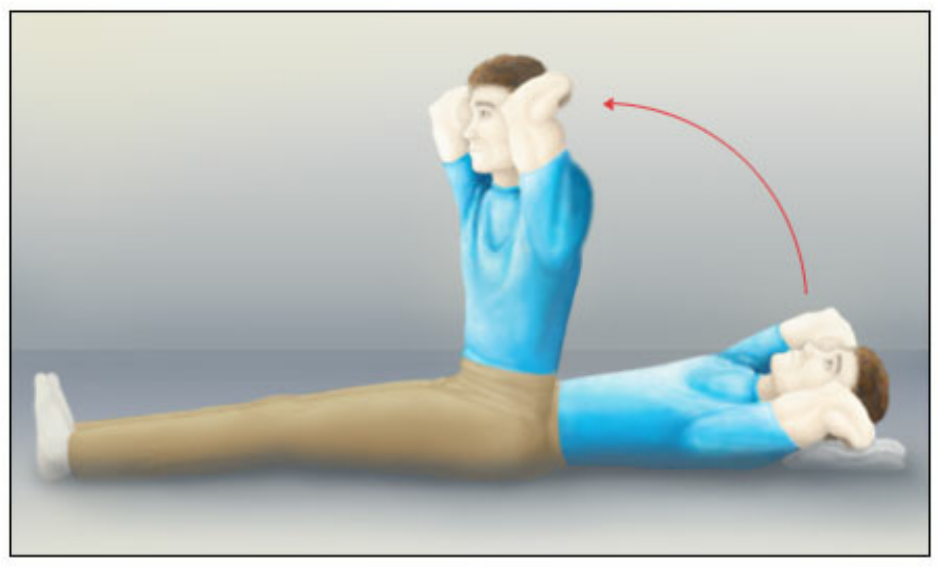

Figure 5. Trunk muscles exercise. Lie on your back, put both hands behind the back of your neck. Then upright yourself to a seating position. Legs should be on the floor during the uprighting movement. You can ask somebody to stabilize your legs. If you cannot reach the seating position, you can do it halfway, that is to 45 degree angle. 


\section{Conclusion}

Spine problems are stated to be common problems among dentists and dental auxiliary personnel. In order to reduce spine problems, correct postural practices, relaxation interval sessions during work, and weight monitoring could be utilized.

It is concluded postural problems leading to neck and backache reported from the dental personnel in Riyadh, Saudi Arabia are comparable to those from other countries. Further studies should address the financial considerations in relation to work loss as attributed by neck and back pain.

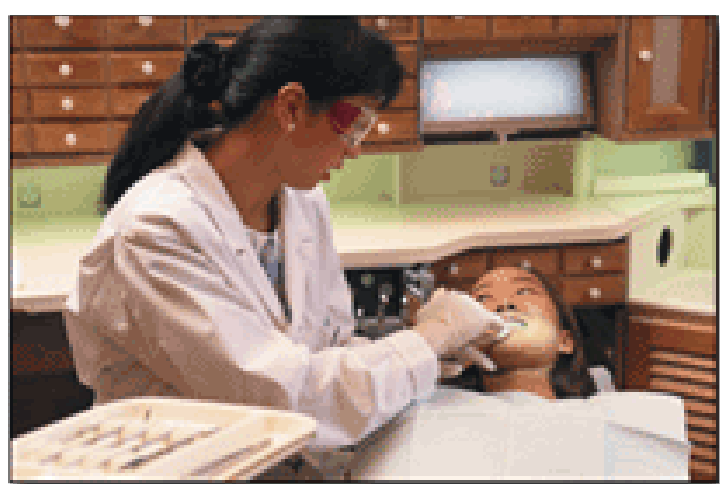

\section{References}

1 McRea R. Clinical orthopedic examination. 3rd edition. Churchill Livingstone, Longman Group, London, UK. 1990.

2. Rowe ML. Low back pain in industry. A position paper. J Occup Med. 1969 Apr;11(4):161-9. No abstract available.

3. Ishmael WK, Shorbe HB. Care of the back. 2nd ed. J.B. Lippincott Company, Toronto, Canada, 1976.

4. Osborn JB, Newell KJ, Rudney JD, Stoltenberg JL. Musculoskeletal pain among Minnesota dental hygienists. J Dent Hyg. 1990 Mar;64(3):132-8.

5. Marshall ED, Duncombe LM, Robinson RQ, Kilbreath SL. Musculoskeletal symptoms in New South Wales dentists. Aust Dent J. 1997 Aug;42(4):240-6.

6. Bassett S. Back problems among dentists. J Can Dent Assoc. 1983 Apr;49(4):251-6. No abstract available.

7. Walters E. How to live with failure and stress. Dent Manage. 1976 Oct;16(11):20-4. No abstract available.

8. Fox JG, Jones JM. Occupational stress in dental practice. Br Dent J. 1967 Nov 21;123(10):465-73. No abstract available.

9. Paul E. The technique of seated dentistry. Quint Int Dent Dig. 1979;10:19.

10. Bers GS. The dentist's health. J Am Dent Assoc. 1980 Apr;100(4):507. No abstract available.

11. Willee AW. How to avoid the occupational hazards of dentistry. Aust Dent J. 1967 Aug;12(4): 348-59. No abstract available.

12. Green EJ, Brown ME. Body mechanics applied to the practice of dentistry. J Am Dent Assoc. 1963;67:679-97.

13. Chowanadisai S, Kukiattrakoon B, Yapong B, Kedjarune U, Leggat PA. Occupational health problems of dentists in southern Thailand. Int Dent J. 2000 Feb;50(1):36-40.

14. Visser JL, Straker LM. An investigation of discomfort experienced by dental therapists and assistants at work. Aust Dent J. 1994 Feb;39(1):39-44.

15. Biller FE. Occupational hazards in dental practice. Oral Hygiene. 1946; 36:1194.

16. Nutter P. Aerobic exercise in the treatment and prevention of low back pain. Occup Med. 1988 Jan-Mar;3(1):137-45. Review. 


\section{Khalid A. Al Wazzan, BDS, MS}

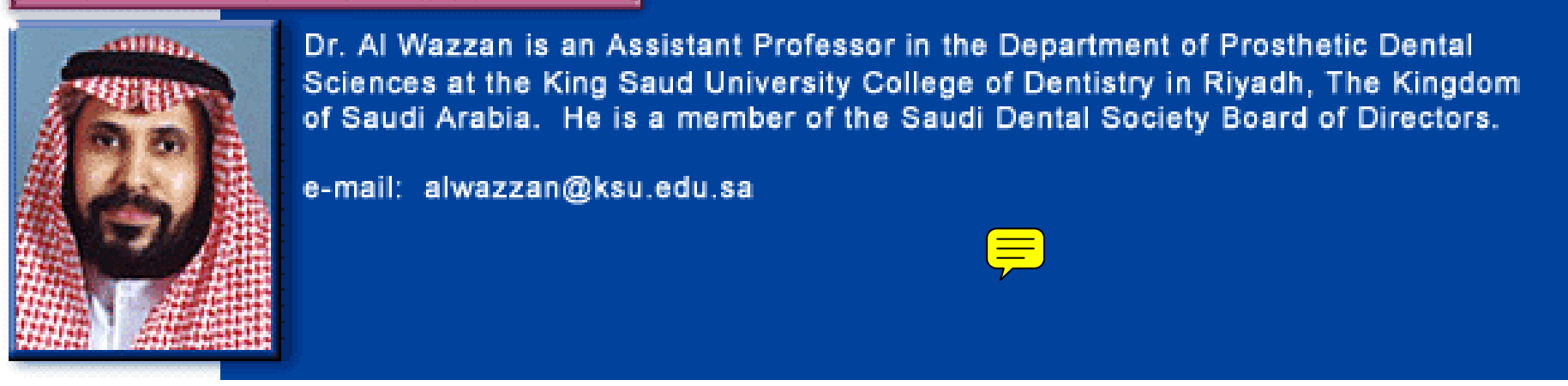

\section{Khalid Almas, BDS, MSc, FRACDS, FDSRC, DDPHRCS, FICD}

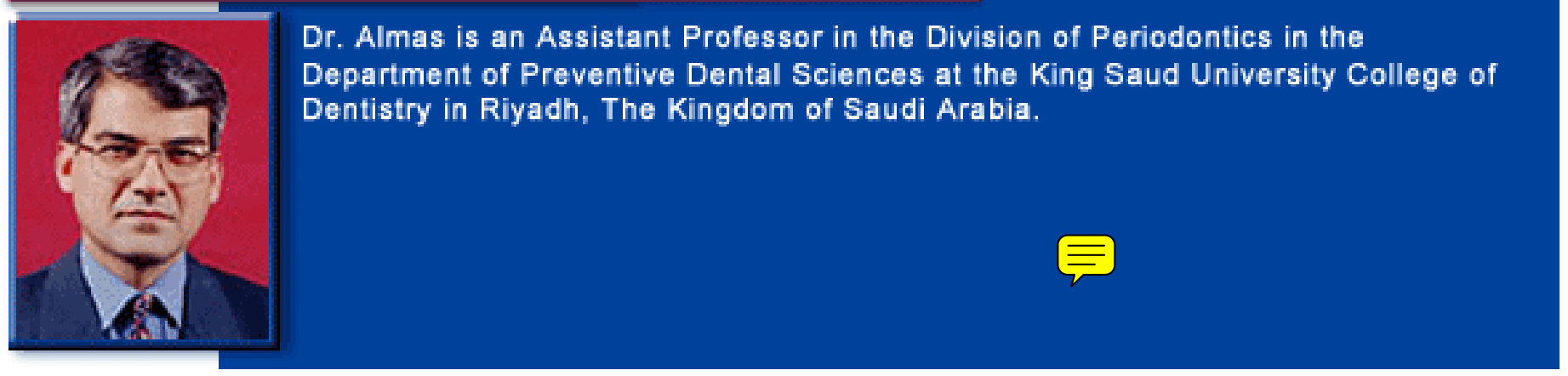

\section{Salah E. Al Shethri, BDS}

\section{$\overline{\overline{\bar{E}}}$}

Dr. Salah E. Al Shethri serves as a Clinical Demonstrator in the Department of Restorative Dental Sciences at the King Saud University College of Dentistry in Riyadh, The Kingdom of Saudi Arabia.

\section{Mohammed Q. Al Qahtani, BDS}

\section{$\equiv$}

Dr. Mohammed Q. Al Qahtani serves as a Clinical Demonstrator in the Department of Restorative Dental Sciences at the King Saud University College of Dentistry in Riyahd, The Kingdom of Saudi Arabia.

\section{Acknowledgement}

The authors are thankful to all the respondents in this study. We also appreciate the help of Dr. Nazeer Khan for his help in the data analysis and Dr. Maamoun K. Kremli (Associate Professor, Head of Orthopedic Surgery Division, College of Medicine) for his valuable assistance 